\title{
The use of crude glycerin as an alternative to reduce fermentation losses and enhance the nutritional value of Piatã grass silage
}

\author{
Marco Antonio Previdelli Orrico Junior ${ }^{1 *}$, José Augusto Velazquez Duarte ${ }^{2}$, Carla Crone ${ }^{1}$, \\ Franciely de Oliveira Neves ${ }^{1}$, Ricardo Andrade Reis ${ }^{3}$, Ana Carolina Amorim Orrico ${ }^{1}$, Alice Watte \\ Schwingel ${ }^{4}$, Danielle Marques Vilela ${ }^{5}$
}

\footnotetext{
1 Universidade Federal da Grande Dourados, Faculdade de Ciências Agrárias, Dourados, MS, Brazil.

2 Universidad Nacional de Asunción, Facultad de Ciencias Agrarias, Pedro Juan Caballero, Paraguay.

${ }^{3}$ Universidade Estadual Paulista “Júlio de Mesquita Filho", Faculdade de Ciências Agrárias e Veterinárias, Departamento de Zootecnia, Jaboticabal, SP Brazil.

${ }^{4}$ Universidade Estadual Paulista "Júlio de Mesquita Filho", Faculdade de Ciências Agronômicas, Botucatu, SP, Brazil.

${ }^{5}$ Universidade Federal da Grande Dourados, Faculdade de Ciências Biológicas e Ambientais, Dourados, MS, Brazil.
}

\begin{abstract}
The objective of this study was to evaluate fermentation losses and the nutritional value of silage of Brachiaria brizantha cv BRS Piatã ensiled with different levels of crude glycerin. The experiment followed a $4 \times 2$ completely randomized factorial design with four doses of crude glycerin $\left(0,100,200\right.$, and $300 \mathrm{~g} \mathrm{~kg}^{-1}$ of DM silage) and two cutting ages (45 and 60 days) with four replicates per treatment (silos). The parameters of dry matter losses, effluents losses, gas losses, $\mathrm{pH}$, microbial population, and nutritional value of the silage were evaluated. There was no difference in $\mathrm{pH}$ among the tested doses of crude glycerin. However, reductions in dry matter and gas losses were observed as a function of crude glycerin doses. Bacterial populations of lactic acid and facultative mesophilic anaerobes also increased as a function of crude glycerin inclusion. Crude glycerin increased ether extract levels and reduced neutral detergent fiber and acid detergent fiber concentrations (dilution effect), improving chemical composition of the silage. Crude glycerin can be used in the ensiling of Piatã grass and the dose of $300 \mathrm{~g} \mathrm{~kg}^{-1}$ of DM yields the best results.
\end{abstract}

Key Words: biodiesel, byproduct, forage conservation, glycerol, ruminants

\section{Introduction}

Biodiesel production generates significant amounts of crude glycerin as byproduct. For every ton of biodiesel produced, $100 \mathrm{~kg}$ of crude glycerin are generated, configuring a yield of $10 \%$ (ANP, 2015). In Brazil, the production of crude glycerin in 2014 was approximately 460,000 tons, greater than the current demand of 40,000 tons (ANP, 2015). Crude glycerin surplus from biodiesel industries represents a hazard risk due to its pollutant content (considerable levels of glycerol and residual lipids). For this reason, alternative usage for this byproduct must be evaluated to reach equilibrium between demand and production ensuring sustainable usage.

Received: February 12, 2017

Accepted: June 7, 2017

*Corresponding author: marcoorrico@yahoo.com.br

http://dx.doi.org/10.1590/S1806-92902017000800002

How to cite: Orrico Junior, M. A. P.; Velazquez Duarte, J. A.; Crone, C.; Neves, F. O.; Reis, R. A.; Orrico, A. C. A.; Schwingel, A. W. and Vilela, D. M. 2017. The use of crude glycerin as an alternative to reduce fermentation losses and enhance the nutritional value of Piatã grass silage. Revista Brasileira de Zootecnia 46(8):638-644.

Copyright (C) 2017 Sociedade Brasileira de Zootecnia. This is an Open Access article distributed under the terms of the Creative Commons Attribution License (http://creativecommons.org/licenses/by/4.0/), which permits unrestricted use, distribution, and reproduction in any medium, provided the original work is properly cited.
Crude glycerin has the potential to be used as an additive to enhance silage fermentation because it has glycerol in its composition. This is a rich source of energy for anaerobic microorganisms (Santos et al., 2014; Carvalho et al., 2017), which can favor microbial growth and improve the quality of fermentation and forage conservation.

The inclusion of crude glycerin in the process of ensiling has been focused on sugar cane. This has been associated to better fermentation, lower production of ethanol, lower dry matter (DM) losses, and silage with superior nutritional value (Santos et al., 2014; Carvalho et al., 2017). The inclusion of crude glycerin has not been tested in the ensiling of grass. In this case, lower levels of soluble carbohydrates and dry matter found in grass seems to be the major limitation point. This is relevant regarding tropical grasses such as Brachiaria brizantha (Mendieta-Araica et al., 2010). Grass may present high buffering capacity, which inhibits fermentation. In addition, several types of yeast that support fermentation in sugarcane silages are not present in grass. These factors may restrain acidification, limit the quality of silage, and configure bottlenecks towards the use of crude glycerin as an alternative to reduce fermentation loss and improve the nutritional value of grass silage.

The addition of low-cost sources of soluble carbohydrates may tackle some limitation points. The 
challenge would be to make ensiling of grass feasible by increasing the growth rates of lactic acid bacteria, dropping silage $\mathrm{pH}$, and enhancing fermentation (Keady and Kiely, 1998; McDonald and Henderson, 1962; Nishino et al., 2012; Chen et al., 2016). If possible, this would configure alternative usage of a potentially pollutant byproduct from biofuel production.

In this sense, aiming to support livestock production, this study was designed to verify if the inclusion of crude glycerin could improve fermentation and the nutritional value of silages prepared with Brachiaria brizantha cv Piatã.

\section{Material and Methods}

The research was conducted in Dourados, MS, Brazil $\left(22^{\circ} 13^{\prime} 18^{\prime \prime} \mathrm{S}\right.$ latitude and $54^{\circ} 48^{\prime} 23^{\prime \prime} \mathrm{W}$ longitude). The climate, according to the Köppen, is Cwa mesothermal humid, with average annual rainfall ranging from 1,250 to $1,500 \mathrm{~mm}$ and temperatures between 20 and $24{ }^{\circ} \mathrm{C}$.

The experiment followed a $4 \times 2$ completely randomized factorial design with four doses of crude glycerin $(0,100$, 200 , and $300 \mathrm{~g} \mathrm{~kg}^{-1}$ of DM silage) and two cutting ages (45 and 60 days), with four replicates per treatment (silos). Experimental silos were built with PVC tubes of $50 \mathrm{~cm}$ in height and $15 \mathrm{~cm}$ in diameter. The silos were sealed at the bottom end with a cap and held approximately $5 \mathrm{~kg}$ of grass.

The crude glycerin used in this study was sampled from a biodiesel industry and presented the following chemical composition: $960.00 \mathrm{~g} \mathrm{~kg}^{-1}$ of dry matter, $64.01 \mathrm{~g} \mathrm{~kg}^{-1}$ of ash, $618.70 \mathrm{~g} \mathrm{~kg}^{-1}$ of glycerol, $61.00 \mathrm{~g} \mathrm{~kg}^{-1}$ of methanol, and $18.03 \mathrm{~g} \mathrm{~kg}^{-1}$ of ether extract.

The area planted with Piatã grass was formed five years prior to the research and was fertilized with $100 \mathrm{~kg} \mathrm{ha}^{-1}$ of nitrogen (urea) 30 days before the beginning of the experiment. On May 25th, 2014 (beginning of the dry season), the grass was evenly cut at a height of $10 \mathrm{~cm}$ above the ground. After standardization, the area was divided into three parts and the grass from each segment was cut as grass reached the specific ages defined in the experiment. A clearing saw was used to cut the grass at a height of $15 \mathrm{~cm}$ above the ground and the collected material was ground to obtain a particle size of $1.5 \mathrm{~cm}$.

Grass samples and different doses of crude glycerin were mixed in plastic bags to establish the experimental treatments (silos). The material for ensiling was manually compacted with a wood rod and the average density was $566 \mathrm{~kg} / \mathrm{m}^{3}$ of fresh matter. After filling, the silos were sealed with plastic sheets and duct tape, weighed, and stored in the laboratory. All components of the silo, as well as the forage material, were weighed to determine the fermentation losses. After 80 days of fermentation, the silo contents were weighed again to determine the gas, effluent, and dry matter losses according to Ping et al. (2016).

Samples of approximately $300 \mathrm{~g}$ of forage from each treatment were collected prior to and after ensiling. Subsequently, these samples were dried at $55{ }^{\circ} \mathrm{C}$ for $72 \mathrm{~h}$ to determine the dry matter content. After pre-drying, the

Table 1 - Chemical composition of Piatã grass with different doses of crude glycerin and two cutting ages

\begin{tabular}{|c|c|c|c|c|c|}
\hline \multirow{2}{*}{ Parameter } & \multirow{2}{*}{$\begin{array}{c}\text { Cutting age } \\
\text { (days) }\end{array}$} & \multicolumn{4}{|c|}{ Dose $\left(\mathrm{g} \mathrm{kg}^{-1}\right.$ of DM) } \\
\hline & & 0 & 100 & 200 & 300 \\
\hline \multirow[t]{2}{*}{ Buffering capacity (meq $\mathrm{HCl} .100 \mathrm{~g}^{-1}$ of $\mathrm{DM}$ ) } & 45 & 6.81 & 6.74 & 6.48 & 6.59 \\
\hline & 60 & 5.55 & 5.66 & 5.80 & 5.76 \\
\hline \multirow[t]{2}{*}{ Dry matter $\left(\mathrm{g} \mathrm{kg}^{-1}\right)$} & 45 & 251.20 & 267.90 & 279.70 & 291.90 \\
\hline & 60 & 329.50 & 338.30 & 350.40 & 370.40 \\
\hline \multirow[t]{2}{*}{ Ash $\left(\mathrm{g} \mathrm{kg}^{-1}\right.$ of DM) } & 45 & 82.70 & 78.20 & 74.30 & 64.30 \\
\hline & 60 & 86.30 & 78.90 & 76.00 & 71.60 \\
\hline \multirow[t]{2}{*}{ Crude protein $\left(\mathrm{g} \mathrm{kg}^{-1}\right.$ of $\left.\mathrm{DM}\right)$} & 45 & 128.70 & 111.40 & 101.90 & 82.10 \\
\hline & 60 & 80.60 & 86.50 & 73.30 & 79.90 \\
\hline \multirow[t]{2}{*}{ Ether extract ( $\mathrm{g} \mathrm{kg}^{-1}$ of DM) } & 45 & 46.00 & 50.60 & 60.70 & 78.90 \\
\hline & 60 & 34.00 & 37.40 & 44.90 & 58.30 \\
\hline \multirow[t]{2}{*}{ Neutral detergent fiber ( $\mathrm{g} \mathrm{kg}^{-1}$ of DM) } & 45 & 621.70 & 553.00 & 523.50 & 504.20 \\
\hline & 60 & 641.80 & 604.20 & 548.30 & 571.50 \\
\hline \multirow[t]{2}{*}{ Acid detergent fiber ( $\mathrm{g} \mathrm{kg}^{-1}$ of $\left.\mathrm{DM}\right)$} & 45 & 292.90 & 289.30 & 274.90 & 253.80 \\
\hline & 60 & 325.90 & 315.30 & 292.60 & 284.60 \\
\hline \multirow[t]{2}{*}{ Non-fibrous carbohydrates ( $\mathrm{g} \mathrm{kg}^{-1}$ of DM) } & 45 & 160.80 & 246.80 & 279.60 & 340.50 \\
\hline & 60 & 142.00 & 177.10 & 230.10 & 241.10 \\
\hline \multirow[t]{2}{*}{ In vitro dry matter digestibility ( $\mathrm{g} \mathrm{kg}^{-1}$ of $\left.\mathrm{DM}\right)$} & 45 & 797.20 & 854.30 & 862.10 & 893.40 \\
\hline & 60 & 762.10 & 832.30 & 826.60 & 844.30 \\
\hline
\end{tabular}

DM - dry matter. 
samples were ground in a Willey mill with 1-mm sieve for further laboratory analysis (Table 1). The concentrations of $\mathrm{DM}$, crude protein $(\mathrm{CP})$, ash, and ether extract (EE) were determined according to the AOAC (1990). The in vitro dry matter digestibility (IVDMD) was evaluated according to the method described by Tilley and Terry (1963). Neutral detergent fiber (NDF) and acid detergent fiber (ADF) were determined according to Mertens (2002).

Non-fibrous carbohydrates (NFC) were calculated by the following equation: $\mathrm{NFC}=100-(\mathrm{NDF}+\mathrm{CP}$ + EE + Ash) proposed by Sniffen et al. (1992). The total digestible nutrient (TDN) values were estimated according to Cappelle et al. (2001). Measurements of aqueous extract and $\mathrm{pH}$ of the material prior to and after ensiling were carried out as proposed by Kung Junior et al. (1984). The buffering capacity was determined in forage samples according to the protocol described by Playne and McDonald (1966).

For microbiological analysis, samples of $25 \mathrm{~g}$ were collected from each silo and placed in flasks with $225 \mathrm{~mL}$ of sterile $1 \%$ peptone water and stirred for $10 \mathrm{~min}$. From the extract obtained, decimal dilutions of 10:1 to 10:7 were prepared to assess the microorganism populations. The number of facultative anaerobic mesophilic bacteria was determined on plates with nutrient agar and incubated at $35{ }^{\circ} \mathrm{C}$. The lactic acid bacteria were numbered on plates with MRS culture medium (Difco) added with $0.4 \%$ nystatin (to prevent fungi growth) and incubated in anaerobic jars (AnaeroGen, Oxoid Ltd.) at $35^{\circ} \mathrm{C}$. Dichloran Glycerol (DG18) agar was used for mold count and the YEPD medium was used for yeast count. The plates were incubated at $28{ }^{\circ} \mathrm{C}$ for five to seven days for fungi count and $48 \mathrm{~h}$ for yeast count (Bravo-Martins et al., 2006).

The results were subjected to analysis of variance, considering the ages of the plants and crude glycerin doses as sources of variation. Orthogonal contrasts were used to assess the linear and quadratic effects of the levels of crude glycerin. Values observed between different plant ages were compared by the F test. All data analyses were performed using the software R (2014).

\section{Results}

Dry matter loss was significantly reduced with the inclusion of crude glycerin, $231.03 \mathrm{~g} \mathrm{~kg}^{-1}$ of ensiled DM in the treatment with $0 \mathrm{~g} \mathrm{~kg}^{-1}$ of DM and $72.64 \mathrm{~g} \mathrm{~kg}^{-1}$ of ensiled DM in the treatment with $300 \mathrm{~g} \mathrm{~kg}^{-1}$ of DM (Table 2).

Effluent losses of $34.63 \mathrm{~g} \mathrm{~kg}^{-1}$ of ensiled DM were observed in the treatment with no glycerin inclusion against $10.36 \mathrm{~g} \mathrm{~kg}^{-1}$ of ensiled DM for the treatment with the highest inclusion level (Table 2). No effluent production was observed in the silage prepared with the 60-day-old grass. With the exception of DM loss ( $\mathrm{P}>0.05)$, the age of the grass significantly influenced fermentation $(\mathrm{P}<0.05)$. Significant increase of the population of lactic acid and facultative anaerobic mesophilic bacteria was observed with the addition of glycerin to the ensiling of Piatã grass (Table 2). Bacterial populations of lactic acid and facultative mesophilic anaerobes were counted at 6.87 and $6.60 \mathrm{log} \mathrm{cfu} / \mathrm{g}$ with no glycerin addition and 7.26 and $7.38 \mathrm{log} \mathrm{cfu} / \mathrm{g}$ with inclusion of $300 \mathrm{~g} \mathrm{~kg}^{-1} \mathrm{DM}$ of crude glycerin, respectively.

Populations of molds $(\mathrm{P}<0.01)$ and yeasts $(\mathrm{P}<0.05)$ also showed significant differences as a function of the levels of crude glycerin, especially in the two highest inclusion levels (Table 2). The average population of molds and yeast was 2.32 and $2.83 \mathrm{log}$ cfu. $\mathrm{g}^{-1}$ for the silage added with $300 \mathrm{~g} \mathrm{~kg}^{-1}$ of DM of crude glycerin, respectively.

In terms of the nutritional value of silage, reductions were observed in the concentrations of NDF and ADF $(\mathrm{P}<0.01)$ with increasing levels of crude glycerin (Table 3 ). Moreover, the inclusion of higher levels of crude glycerin was related to higher concentration of IVDMD [769.68 (0 $\mathrm{g} \mathrm{kg}^{-1}$ of DM of crude glycerin); 841.55 (300 $\mathrm{g} \mathrm{kg}^{-1}$ of DM of crude glycerin)] and TDN [777.46 $\left(0 \mathrm{~g} \mathrm{~kg}^{-1}\right.$ of DM of crude glycerin); 853.64 (300 $\mathrm{g} \mathrm{kg}^{-1}$ of DM of crude glycerin)] $(\mathrm{P}<0.01)$.

\section{Discussion}

The age of the grass used for ensiling was associated to different amounts of gas loss, lower with silos prepared with mature grass (Table 2). Likewise, this was reported by Dias et al. (2014), assigning lower gas losses to greater amounts of dry matter present in the silage of mature sugarcane. Younger grass may present excessive moisture, which inhibits effective fermentation (Collins and Owens, 2003). In silages, poor fermentation becomes problematic when moisture levels exceed $70 \%$ and soluble carbohydrates are scarce (less than $50 \mathrm{~g} \mathrm{~kg}^{-1} \mathrm{DM}$ ) (Collins and Owens, 2003).

In this study, all levels of crude glycerin inclusion were associated to notable reduction of DM losses, from 231.03 to $72.64 \mathrm{~g} \mathrm{~kg}^{-1}$ of ensiled DM (Table 2). This is probably related to more efficient fermentation during ensiling. Most likely, the inclusion of crude glycerin itself would not explain such a distinguished decrease ( $68.86 \%$ of DM), considering that the maximum level added to the silos was $300 \mathrm{~g} \mathrm{~kg}^{-1}$ of DM (30\%). Using $100 \mathrm{~g}$ of glycerin $\mathrm{kg}^{-1}$ of DM, the level 

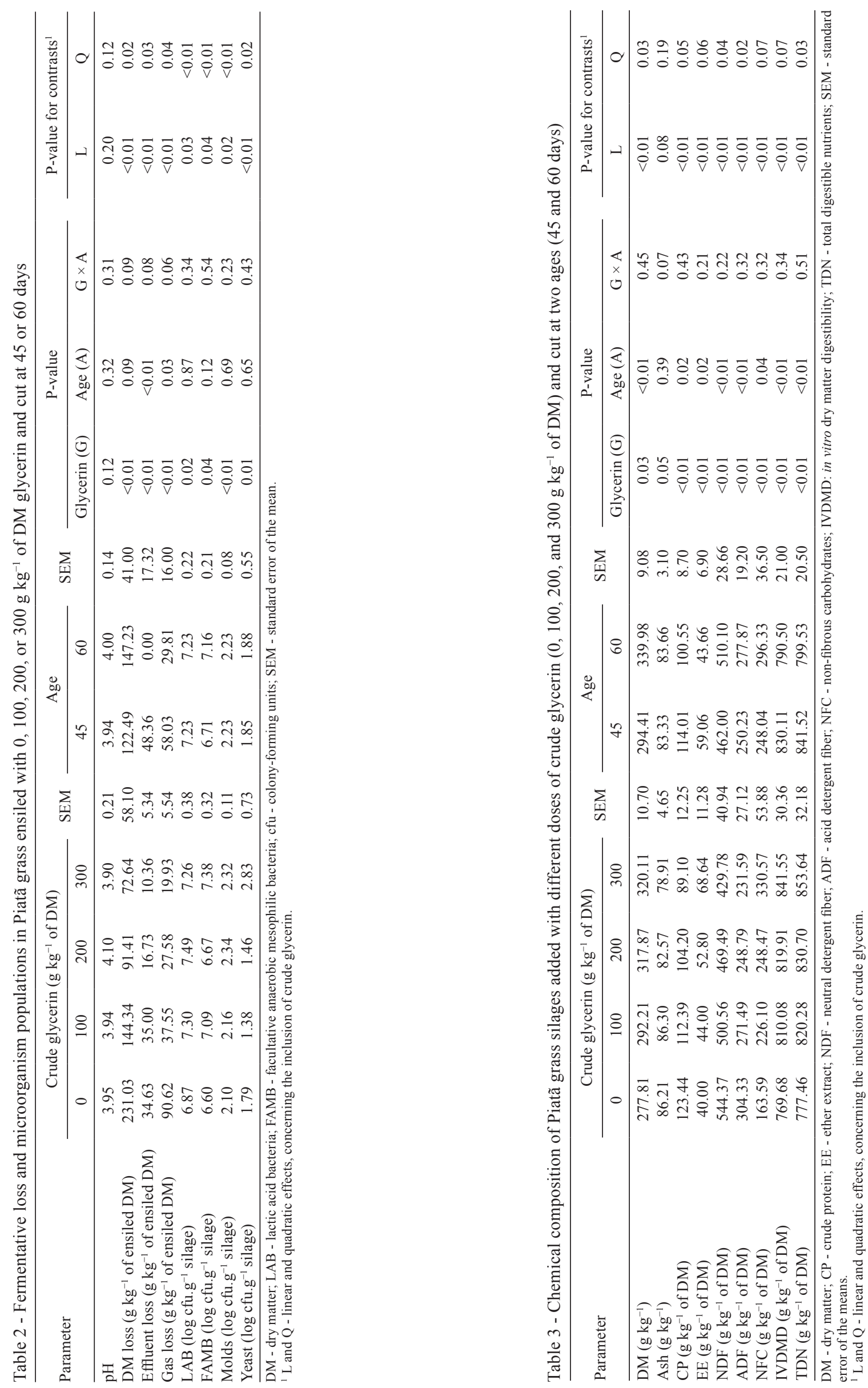
of DM losses was $22.39 \%$ (from 231.03 to $144.34 \mathrm{~g} \mathrm{~kg}^{-1}$ DM). These values are consistent with the results reported by Carvalho et al. (2017), comparing different levels of inclusion in sugarcane silage. These authors reported reductions of $20.28 \%$ of DM losses by adding Lactobacillus hilgardii and $80 \mathrm{~g} \mathrm{~kg}^{-1} \mathrm{DM}$ of glycerin.

The decrease of gas losses was also observed with increasing levels of crude glycerin inclusion. Gas losses decreased on average by $78 \%$ when comparing the lowest with the highest level of crude glycerin inclusion. Gas losses are related to the type of fermentation during ensiling, which tends to decrease when homofermentative bacteria predominate. In this case, the bacterial metabolism of soluble carbohydrates leads to the production of lactic acid, important to drop silage $\mathrm{pH}$. In contrast, heterofermentative inoculants are related to the production of alcohol, and acetic and butyric acids, associated to greater gas losses during ensiling (Viana et al., 2013).

The supposition of more efficient fermentation associated to increasing levels of crude glycerin inclusion may be addressed to the fact that Lactobacillus strains break down glycerol as a source of energy (Garai-Ibabe et al., 2008; Pasteris and Strasser de Saad, 2009). In the present study, the most expressive number of microorganisms was addressed to lactic acid bacteria. This type of bacteria is usually related to the decrease of DM losses due to greater acidification during ensiling (Goeser et al., 2015).

The increase in the growth rates of lactic acid bacteria were not associated to the final $\mathrm{pH}$ in any silage $(\mathrm{P}>0.05)$. The final $\mathrm{pH}$ of the silage is usually related to the quality of fermentation, but does not necessarily explain the speed in which $\mathrm{pH}$ drops, neither the type of fermentation (microorganism populations), nor the nutritional value of the silage. Still, the dry matter and gas losses observed in the present study are suggestive of rapid decline of $\mathrm{pH}$ during fermentation as a result of the inclusion of crude glycerin. This was also discussed by Goeser et al. (2015) and reported by Santos et al. (2014), testing the effect of the inclusion of crude glycerin and microbial additives to sugarcane silage. In addition, these authors observed an increment in the energy density of sugarcane silage.

Microorganisms such as yeast and molds use glycerol as a source of energy (Taccari et al., 2012). Thus, the inclusion of crude glycerin was expected to increase the population of these types of microorganisms in the silage. These are undesired microorganisms, related to hygienic and nutritional aspects of the silage (Bravo-Martins et al., 2006). However, the population of yeast and molds increased in a level (Table 2) considered irrelevant to configure any depreciation in the quality of the silages (Cogan et al., 2016).
All silages were considered to show good quality in terms of microbiology.

The nutritional value of the silages was in accordance with the expectations. Greater amounts of NDF $\left(510.10 \mathrm{~g} \mathrm{~kg}^{-1}\right.$ of $\mathrm{DM})(\mathrm{P}<0.01)$ were related to more mature grass (60 days at cutting), probably due to greater proportions of cell wall. The composition of crude glycerin, i.e., mainly non-fibrous carbohydrates, reduced the proportions of NDF and ADF with increasing levels of crude glycerin, which is related to the dilution effect (Table 3). Martins et al. (2014) observed reductions by 25.3 and $24.7 \%$ of NDF when $450 \mathrm{~g} \mathrm{~kg}^{-1}$ of DM of glycerin was added to silage produced with corn and sunflower, respectively.

Likewise, the linear reduction $(\mathrm{P}<0.01)$ in $\mathrm{CP}$ concentration, related to glycerin inclusion, may be also related to a dilution effect (Table 3). Similar results were reported by Gomes et al. (2015), who observed a reduction by $37.56 \%$ in the $\mathrm{CP}$ concentration of sugarcane silages added with $150 \mathrm{~g} \mathrm{~kg}^{-1}$ of fresh matter glycerin compared with control silages. This is often reported because additives used to promote fermentation are rich in energy and present low protein content.

The association of crude glycerin inclusion and superior amounts of EE, IVDMD, and TDN (Table 3) is probably due to the composition of the additive used for ensiling. The byproduct sampled from biodiesel production consisted of low-purity glycerin (high levels of residual lipids originated from vegetable oils). This is relevant to livestock production because high amounts of $\mathrm{EE}$ in the diet, usually above $70 \mathrm{~g} \mathrm{~kg}^{-1}$ of DM, may reduce intake as a consequence of poor microbiological degradation of fiber in the rumen (Doreau and Ferlay, 1995; Gudla et al., 2012; Buccioni et al., 2012; Manso et al., 2016). However, the EE concentration observed in the silages was considered as within suitable intervals for intake (Table 3).

A disadvantage of using silages prepared with tropical grasses is associated to low energy concentration (TDN) for animal feed. Dietary energy in grass silage may be considerably low compared with corn or sorghum silages (Carvalho et al., 2016), which may be compensated by offering greater proportions of concentrate to ensure weight gain in animal production systems. However, this may configure considerable increases in the production costs.

An average increase by $2.5 \mathrm{~g}^{\mathrm{T} D N ~ \mathrm{~kg}^{-1}}$ of DM was observed for each inclusion of $10 \mathrm{~g} \mathrm{~kg}^{-1}$ of DM crude glycerin in the silage, reaching a maximum of $853.64 \mathrm{~g}$ of TDN kg-1 of DM. The increased nutritional value of the silage was probably related to the energetic value of the crude glycerin, which enabled lactic acid bacteria to grow and optimize fermentation. It is noteworthy that 
energetic additives, such as molasses and pure glycerol, would probably enable superior results. However, lowcost additives seem to be the key to make the inclusion of additives and the ensiling of grass feasible. In contrast, low-price additives may present little amount of glycerol, which could result in poor fermentation.

Currently, there is little information regarding intake (acceptability) of silages containing crude glycerin. Therefore, consistent contribution towards livestock performance is incipient. However, the results reported in this study are convincing that the inclusion of crude glycerin may alleviate fermentative losses and generate grass silage with superior nutritional value. Overall, the results are potential contributions to support sustainable livestock production within tropical regions and scenarios of biodiesel production.

\section{Conclusions}

The use of crude glycerin in the ensiling of Piatã grass is recommended to increase the population of lactic acid bacteria, reduce fermentation losses, and improve the nutritional value of silage. Overall, the dose of $300 \mathrm{~g} \mathrm{~kg}^{-1}$ of dry matter crude glycerin (in relation to the ensiled dry matter) yields the best results.

\section{Acknowledgments}

This study was carried out with the financial support of the Universidade Federal da Grande Dourados (UFGD) and the Fundação de Apoio ao Desenvolvimento do Ensino, Ciência e Tecnologia do Estado de Mato Grosso do Sul (FUNDECT). In addition, the authors would like to thank the Coordenação de Aperfeiçoamento de Pessoal de Nível Superior (CAPES) for granting the Master degree scholarship.

\section{References}

ANP - Agência Nacional do Petróleo. Dados estatísticos. Available at: $<$ http://www.anp.gov.br/?id=472. $>$. Accessed on: Aug. 03, 2016.

AOAC - Association of Official Analitical Chemists. 1990. Official methods of analysis. 15th ed. AOAC International, Arlington, VA.

Bravo-Martins, C. E. C.; Carneiro, H.; Castro-Gómez, R. J.; Figueiredo, H. C. P. and Schwan, R. F. 2006. Chemical and microbiological evaluation of ensiled sugarcane with different additives. Brazilian Journal of Microbiology 37:499-504.

Buccionia, A.; Decandiab, M.; Minieria, S.; Molleb, G. and Cabiddub, A. 2012. Lipid metabolism in the rumen: New insights on lipolysis and biohydrogenation with an emphasis on the role of endogenous plant factors. Animal Feed Science and Technology 174:1-25.

Cappelle, E. R.; Valadares Filho, S. C.; Silva, J. F. C. and Cecon, P. R. 2001. Estimativas do valor energético a partir de características químicas e bromatológicas dos alimentos. Revista Brasileira de Zootecnia 30:1837-1856.

Carvalho, B. F.; Avila, C. L. S.; Pereira, M. N. and Schwan, R. F. 2017. Methylotrophic yeast, lactic acid bacteria and glycerin as additives for sugarcane silage. Grass and Forage Science 72:355-368. doi: $10.1111 /$ gfs. 12248 .

Carvalho, W. G.; Costa, K. A. P.; Epifanio, P. S.; Perim, R. C.; Teixeira, D. A. A. and Medeiros, L. T. 2016. Silage quality of corn and sorghum added with forage Peanuts. Revista Caatinga 29:465-472.

Chen, L.; Gang Guo, B.; Xianjun Yuan, A.; Jie Zhang, A.; Lia, J. and Shaoa, T. 2016. Effects of applying molasses, lactic acid bacteria and propionic acid on fermentation quality, aerobic stability and in vitro gas production of total mixed ration silage prepared with oat-common vetch intercrop on the Tibetan Plateau. Journal of the Science of Food and Agriculture 96:1678-1685.

Cogan, T.; Hawkey, R.; Higgie, Lee, M. R. F.; Mee, E.; Parfitt, D.; Raj, J.; Roderick, S.; Walker, N.; Ward, P. J. and Wilkinson, M. 2016. Silage and total mixed ration hygienic quality on commercial farms: implications for animal production. Grass and Forage Science, doi: 10.1111/gfs.12265 (in press).

Collins, M. and Owens, V. N. 2003. Preservation of forage as hay and silage. p.443-471. In: An introduction to grassland agriculture. 6th ed. Barnes, R. F., ed. Iowa State Press, Ames.

Dias, A. M.; Ítavo, L. C. V.; Ítavo, C. C. B. F.; Blan, L. R.; Gomes, E. N. O.; Soares, C. M.; Leal, E. S.; Nogueira, E. and Coelho, E. M. 2014. Ureia e glicerina bruta como aditivos na ensilagem de canade-açúcar. Arquivo Brasileiro de Medicina Veterinária e Zootecnia 66:1874-1882.

Doreau, M and Ferlay, A. 1995. Effect of dietary lipids on nitrogen metabolism in the rumen: a review. Livestock Production Science 43:97-110

Garai-Ibabe, G.; Ibarburu, I.; Berregi, I.; Claisse, O.; Lonvaud-Funel, A.; Irastorza, A. and Dueñas, M. T. 2008. Glycerol metabolism and bitterness producing lactic acid bacteria in cidermaking. International Journal of Food Microbiology 121:253-261.

Goeser, J. P.; Heuer, C. R. and, Crump, P. M. 2015. Forage fermentation product measures are related to dry matter loss through metaanalysis. The Professional Animal Scientist 31:137-145.

Gomes, M. A. B.; Moraes, G. V.; Jobim, C. C.; Santos, T. C.; Oliveira, M. R. and Rossi, R. M. 2015. Aerobic stability, chemical composition and ruminal degradability of sugarcane silage with glycerin from biodiesel. Semina: Ciências Agrárias 36:1531-1544.

Gudla, P.; Abughazaleh, A. A.; Ishlak, A. and Jones, K. 2012. The effect of level of forage and oil supplement on biohydrogenation intermediates and bacteria in continuous cultures. Animal Feed Science and Technology 171:108-116.

Keady, T. W. J and Kiely, P. O. 1998. An evaluantion of potassium and nitrogen fertilization of grassland, and date of harvest, on fermentation, effluent production, dry-matter recovery and predicted feeding value of silage. Grass and Forage Science 53:326-337.

Kung Junior, L.; Grieve, D. B.; Thomas, J. W. and Huber, J. T. 1984. Added ammonia or microbial inocula for fermentation and nitrogenous compounds of alfalfa ensiled at various percents of dry matter. Journal of Dairy Science 67:299-306.

Manso, T; Gallardo, B; Guerra-Rivas, C. 2016. Modifying milk and meat fat quality through feed changes. Small Ruminant Research 142:31-37.

Martins, A. S.; Oliveira, J. R.; Lederer, M. L.; Moletta, J. L.; Galetto, S. and Pedrosa, V. B. 2014. Glycerol inclusion levels in corn and sunflower silages. Ciência Agrotecnologia 38:497-505.

McDonald, P. and Henderson, A. R. 1962. Buffering capacity of herbage samples as a factor in ensilage. Journal of the Science Food and Agriculutre 13:395-400.

Mendieta-Araica, B.; Sporndly, E.; Reyes-Sanchez, N.; Norell, L and Sporndly, R. 2010. Silage quality when Moringa oleifera is 
ensiled in mixtures with Elephant grass, sugar cane and molasses. Grass and Forage Science 64:364-373.

Mertens, D. R. 2002. Gravimetric determination of amylase-treated neutral detergent fiber in feeds with refluxing beakers or crucibles: collaborative study. Journal of Association of Official Analytical Chemists International 85:1217-1240.

Nishino, N.; Li, Y.; Wang, C. and Parvin, S. 2012. Effects of wilting and molasses addition on fermentation and bacterial community in guinea grass silage. Letters in Applied Microbiology 54:175-181.

Pasteris S. E. and Strasser de Saad, A. M. 2009. Sugar-Glycerol cofermentations by Lactobacillus hilgardii isolated from wine. Journal of Agricultural and Food Chemistry 57:3853-3858.

Ping, Li.; Shuren, Ji; Wang, Q.; Qin, M.; Hou, C. and Shen, Y. 2017. Adding sweet potato vines improve the quality of rice straw silage. Animal Science Journal 88:625-632. doi: 10.1111/asj.12690.

Playne, M. J. and MacDonald, P. 1966. The buffering constituents of herbage and of silage. Journal of the Science of Food and Agriculture 17:264-268.
Santos, W. P.; Carvalho, B. F; Avila, C. L. S.; Dias Junior, G. S.; Pereira, M. N. and Schwan, R. F. 2014. Glycerin as an additive for sugarcane silage. Annals of Microbiology 65:1547-1556.

Sniffen, C. J.; O'Connor, J. D.; Van Soest, P. S.; Fox, D. G. and Russell, J. B. 1992. A net carbohydrate and protein system for evaluating cattle diets II. Carbohydrate and protein availability. Journal of Animal Science 70:3562-3577.

Taccari, M.; Canonico, L.; Comitini, F.; Mannazzu, I. and Ciani, M. 2012. Screening of yeasts for growth on crude glycerol and optimization of biomass production. Bioresource Technology 110:488-495.

Tilley, J. M. A. and Terry, R. A. 1963. A two-stage technique for the in vitro digestion of forage crop. Grass and Forage Science 18:104-111.

Viana, P. T.; Teixeira, F. A.; Pires, A. J. V.; Carvalho, G. G. P.; Figueiredo, M. P.; Santana Júnior, H. A. 2013. Losses and nutritional value of elephant grass silage with inclusion levels of cottonseed meal. Acta Scientiarum. Animal Sciences 35:139-144. 